model of the new locomotive SO 17-635 which recently completed a successful test journey of 13,000 miles hauling a goods train of 1,200 tons. This engine is an outstanding development of the steam locomotive and, in its way, a pioneer, having been designed for the conditions of Middle Asia and the Far East where, owing to the scarcity of water, the provision of adequate supplies may represent as much as 40 per cent of the total cost of construction. The engine has a special tender equipped with radiators for condensing the exhaust steam, and tanks for collecting the condensate. After being passed first through an oil separator, the exhaust steam enters a turbine which drives the fans for cooling the steam when it reaches the radiators. In this way, with an initial supply of 10 tons of water, it is claimed that the engine can make a run of 627 miles without replenishment. The trial trip was organized for the purpose of testing the behaviour of this locomotive in severe winter conditions, with different kinds of coal, and on the steep gradients which are numerous in the mountainous districts. Travelling from Moscow to Vladivostok and back, it passed over eleven main lines of the U.S.S.R., and the long run, it is stated, was completed without a hitch. Further Soviet exhibits at the Paris Exhibition will include working models of other steam and electric locomotives and of new types of railway coaches specially adapted to Russian and transSiberian conditions of travel. The growth of railway transport in those regions is indicated by recent official figures, which show that in 1935 the total length of the railways in the U.S.S.R. was 52,500 miles and that last year they carried 990.8 million passengers and $484 \cdot 2$ million tons of freight.

\section{Research in Tropical Medicine}

THRes junior fellowships are offered immediately by the Medical Research Council for award to qualified medical men wishing to receive training with the view of careers in research work in tropical medicine. The fellowships will be tenable for three years. The stipend will be at the rates of $£ 300, £ 400$ and $£ 500$ per annum in the successive years, with an additional allowance during service abroad and necessary expenses. In three years' time, at least one senior fellowship will be available for candidates who have held the junior fellowships mentioned above. This will be awarded for a further period of three years, carrying stipend at the rate of $£ 600-£ 750$ per annum, with an additional allowance during service abroad and expenses. The time will be spent mainly in research work in the tropics. The Council is also prepared to consider immediate applications for senior fellowships from candidates who have had adequate experience in research work, whether already specially trained in tropical medicine or not. The Council further intends to establish in due course permanent and pensionable appointments for research work in tropical medicine, including senior posts. Members of this research staff will work partly in the tropics, and partly in institutions at home to which they will be severally attached. Further information can be obtained from the Secretary, Tropical Medical Research Committee, 38 Old Queen Street, London, S.W.1, with whom applications should be lodged not later than June 15.

\section{Royal Geographical Society Awards}

THe King has approved the award of the Royal Medals of the Royal Geographical Society as follows : The Founder's Medal to Colonel C. G. Lewis, for his surveys on the Miri Mission, 1911-12, in Iraq and Syria, 1918-19, and on the Afghan and Turco-Iraq Boundary Commissions; for the air survey of the Irrawaddy Delta, 1924; and for his promotion and encouragement of the exploration and survey of the Himalaya; The Patron's Medal to Mr. Lincoln Ellsworth, for his work in developing the technique of aerial navigation in the Polar regions, culminating in his successful flight across the Antarctic in 1935-36. The following awards have been made by the Council : The Murchison Grant to Mr. Ronald Kaulback, for his surveys in South-eastern Tibet; the Back Grant to Mr. L. R. Wager, for his work in mountain physiography; the Cuthbert Peek Grant to Mr. V. E. Fuchs, to assist him in his expedition to Lake Rukwa, East Africa; the Gill Memorial to Mr. George B. Barbour, for his work on the geology and geography of China.

\section{Institution of Electrical Engineers Premium Awards}

THE Institution of Electrical Engineers has made the following award of premiums for papers read during the Session 1936-37, or accepted for publication : Institution Premium to Dr. E. A. Speight and O. W. Gill ; Ayrton Premium to Dr. D. Robertson; Fahie Premium to Col. A. S. Angwin and Mr. R. A. Mack; Kelvin Premium to Dr. T. E. Allibone, D. B. McKenzie and F. R. Perry ; Paris Exhibition (1881) Premium to J. A. Sumner; Overseas Premium to Dr. A. L. Green, Dr. G. Builder and Dr. O. O. Pulley ; Extra Premiums to Dr. P. Dunsheath, L. H. Harris, E. H. Jolley and F. O. Morrell ; H. Trencham and K. J. R. Wilkinson; Mr. W. R. Debenham; Dr. W. Jack. son, Mr. H. A. Thomas; Wireless Section Premiums to Dr. Benjamin, C. W. Cosgrove, and G. W. Warren (Duddell Premium); Commander F. G. Loring, W. L. McPherson and W. H. McAllister, T. L. Eckersley; Meter and Instrument Section Premiums to W. F. Randall ; Dr. E. Hughes ; Dr. C. Dannatt ; Prof. J. T. MacGregor-Morris and Mr. V. A. Hughes; Transmission Section Premiums to H. G. Taylor (Sebastian de Ferranti Premium); J. Eccles.

\section{Radio Communication Conference at Bucharest}

The Fourth Reunion of the Comité Consultatif International des Radiocommunications (C.C.I.R.) will take place in Bucharest on May 21-June 8. The previous meeting was held in Lisbon in 1934 (see NATURE Sept. 29, p. 490), and in the intervening three years the various national committees have investigated miscellaneous technical problems in connexion with radio communication. The matters under discussion at the present time include the study of the propaga- 